Heritage, craft, and identity: twisthands and their machinery in what's left of the British lace industry*

Men's relationship with factory machinery was both simple and complex; an exchange peppered with skills based on facts, rules of thumb, standard practices, and manual and perceptual dexterity. ${ }^{1}$ In part, too, it was a cultural norm. Men's identification with machines was 'self-evident and taken for granted'; frequently part of their upbringing as boys. ${ }^{2}$ Skills were frequently taught via apprenticeships, often as long as those for pre-industrial, hand-tool trades such as instrument making or cobbling. Training was factory floor based: taught as onthe-job learning and supervised by a journeyman. ${ }^{3}$ Skilled male workers, on average, earned some forty to fifty per cent more than unskilled workers, until the differential declined in the 1970s. ${ }^{4}$ The act of mastering complex machinery undoubtedly brought authority, privilege

\footnotetext{
* This study was funded by the AHRC under its Science and Heritage Development programme, as Nottingham lace: capturing and representing knowledge in people, machines and documents. The interviews upon which this article is based were conducted in the factory (fieldwork and interviews 1-11 conducted by Julie Botticello) and at the operatives' homes (interviews 12-16 conducted by Gill Murray) between March and September 2013. The interview references have been anonymised and are listed here simply by date in the order that they were recorded. A majority of operatives were interviewed on more than one occasion.
}

\footnotetext{
${ }^{1}$ Charles More, Skill and the English Working Class, 1870-1914 (London, 1980), 15-16; H.M. Collins, 'Expert systems and the science of knowledge', in Weibe Bijker, Thomas Hughes and Trevor Pinch (eds), The Social Construction of Technological Systems (Cambridge MA, 1987), 329-348.

${ }^{2}$ Ulf Mellström, ‘Machines and masculine subjectivity: technology as an integral part of men's life experiences', Men and Masculinities 16 (2004), 370.

${ }^{3}$ More, Skill, 70, 86.

${ }^{4}$ Guy Routh, Occupation and Pay in Britain 1906-79 (Houndsmill, 1980), 124.
} 
and exclusion. Thus read, skill might be construed as a power discourse; more an exaggerated social construct than a 'genuine' attribute..$^{5}$ Yet skill was a critical part of male working-class culture, operating as a source of pride and respectability. 'Craft skill, and the satisfaction in it,' Ross McKibbin notes, 'did much to mitigate the effects of increasing simplification of industrial routines. ${ }^{9}$ One survey conducted in the 1950s found that 'youths learning skilled trades showed greater interest and personal involvement in the job', which increased 'with the skill demanded by the craft'. ${ }^{7}$ Ferdynand Zweig similarly noted the strong positive correlation between skill and job satisfaction, particularly if the skill was more real than imagined. ${ }^{8}$

Though declining in numbers, skilled men still accounted for between a third and 40 per cent of the British male workforce after the Second World War, and some 30 per cent in the 1960 s. ${ }^{9}$ Today, that number has fallen to below 20 per cent, driven primarily by the collapse in manufacturing. ${ }^{10}$ This demise is read against a backdrop of a broader British national decline and malaise. Implicit is the nostalgic -- and certainly politically constructed - understanding that manufacturing jobs have greater worth than those in the service sector:

\footnotetext{
${ }^{5}$ David Collinson, Managing the Shopfloor: Subjectivity, Masculinity and Workplace Culture (Berlin, 1992), 89-97; Cynthia Cockburn, Machinery of Dominance: Women, Men and Technical Know-How (London, 1985), 9, 34-35; Thomas Steiger, 'Construction skill and skill construction', Work. Employment and Society, 7 (1993), 535-560.

${ }^{6}$ Ross McKibbinn, 'Work and hobbies in Britain, 1880-1950', in Jay Winter (ed.), The Working Class in Modern British History (Cambridge, 1983), 136.

${ }^{7}$ R. F. L. Logan and E. M. Goldberg, 'Rising eighteen in a London suburb: a study of some aspects of the life and health of young men', British Journal of Sociology, 4 (1953), 330.

${ }^{8}$ Ferdynand Zweig, The British Worker (Harmondsworth, 1952), 96-123.

${ }^{9}$ Kevin Whitson, 'Craftsmen and skilled workers in engineering, 1914-64', Labour History Review, 76 (2011), 207-8.

102011 UK Census, Table KS609EW.
} 
that we need to get back to making things, for our social memories of past industrial skills are embedded in a positive understanding of an earlier Britain's economic primacy. ${ }^{11}$ There is no denying the sharp fall in the numbers employed in British manufacturing: down from $8.9 \mathrm{~m}$ to $2.8 \mathrm{~m}$ over the last fifty years. Between 2005-2010 alone, 600,000 manufacturing jobs disappeared, destroying the economic base of many local communities in the North, the Midlands, Scotland and Wales. ${ }^{12}$ Although all G7 countries have experienced similar declines, the drop in the UK has been sharper, so that now manufacturing accounts for only some ten per cent of GDP. ${ }^{13}$ Countless regional industries, such as Staffordshire pottery, knitwear in Leicestershire and shipbuilding in the North-East and Scotland, have all but disappeared, forcing large numbers of men and women out of the labour market onto incapacity-related benefits. ${ }^{14}$ 'We mourn worlds known to be irrevocably lost', and empathise with those whose skills and working traditions are under threat. ${ }^{15}$ There is a genuine anger among those with a 'lived-through memory' of this de-industrialisation, and a 'sadness, loss

\footnotetext{
${ }^{11}$ Jim Tomlinson, The Politics of Decline: Understanding Post-War Britain (London, 2000); Bill Rubenstein, Capitalism, Culture and Decline in Britain, 1750-1990 (London, 1993).

${ }^{12}$ A false idol: Britain's manufacturing sector is changing beyond all recognition', The Economist, Nov 5th 2016; Christina Beatty and Steve Fothergill, Jobs, Welfare and Austerity: How the Destruction of Industrial Britain Casts a Shadow over Present-Day Public Finances (Sheffield, 2016).

${ }^{13}$ Andrew Banks, Sami Hamroush, Ciaren Taylor and Michael Hardie, An International Perspective on the UK: Gross Domestic Product (London, 2014).

${ }^{14}$ Beatty and Fothergill, Jobs, Welfare and Austerity.

${ }^{15}$ David Lowenthal, The Heritage Crusade and the Spoils of History (Cambridge, 1998), xv.
} 
and pride' among the few still connected to such industries. ${ }^{16}$ Such loss, it is argued, has led to a particular crisis in working-class male identity in Britain and elsewhere. ${ }^{17}$

According to Robert Hewison, the British inability to cope with decline has fostered a proliferation of air-brushed mythologised 'history' as 'heritage' to distract from contemporary industrial woes. ${ }^{18}$ Survey data has shown, for example, that nostalgia forms a significant component of many visitors' experience to open air industrial museums. ${ }^{19}$ Objects, collections, buildings, etc., it is argued, become recognized as heritage only when they come to signify certain values -- or lost values -- within contemporary society. If this is true, then the physical heritage of factories and machinery can only be understood and interpreted through the intangible. ${ }^{20}$ Bygone skills are in themselves part of our intangible past: our former lived experiences. ${ }^{21}$ Smith and Waterson argue that heritage is not 'simply' about identity: it is also about creating and maintaining a sense of place, not only physically

\footnotetext{
${ }^{16}$ Alice Mah, Industrial Ruination, Community and Place: Landscapes and Legacies of Urban Decline
} (Toronto, 2012), 82-6.

${ }^{17}$ Michael Kimmel, 'The contemporary “crisis” of masculinity in historical perspective', in Harry Brod (ed.), The Making of Masculinities: The New Men's Studies (Boston, 1987), 121-153; Ava Baron, 'Masculinity, the embodied male worker, and the historian's gaze', International Labour and Working-Class History, 69 (2006), 143-160; Chitra Joshi, 'On "de-industrialization" and the crisis of male identities', International Review of Social History, 47 (2002), 159-175.

${ }^{18}$ Robert Hewison, The Heritage Industry: Britain in a Climate of Decline (London, 1987), 137-8.

${ }^{19}$ Lara Rutherford-Morrison, 'Playing Victorian: heritage, authenticity, and make-believe in Blists Hill Victorian town, the Ironbridge Gorge', The Public Historian, 37 (2015), 86. For an overview of living history see Raphael Samuel, Theatres of Memory: Past and Present in Contemporary Culture (London, 1994), 169-202. ${ }^{20}$ Dawson Munjeri, 'Tangible and intangible heritage: from difference to convergence', Museum International, 56 (2004), 13.

${ }^{21}$ Laurajane Smith, Paul Shackel and Gary Campbell, 'Class still matters', in Smith, Shackel and Campbell (eds), Heritage, Labour and the Working Classes (Abingdon, 2011), 9. 
but as a social space in which we and others can locate ourselves. ${ }^{22}$ That space is a complex construct, moulded and determined by external professional, media and popular discourses, as well as by personal recollection.

This study focuses on lace-making in an East Midlands factory. Cluny Lace in Ilkeston, just outside Nottingham, is the last remaining Leavers factory in Britain. The Leavers machine, one commentator noted, in imitating hand-lace production, is a 'triumph of mechanical ingenuity', producing the 'finest and most delicate fabric ... to supply by parts of an ingenious apparatus the delicacy of touch and the dexterity of clever hands. ${ }^{23}$ The men using the machines, like the factory itself, belong almost to a bygone age where heuristic knowledge and rules still dominate. This is old, albeit complicated, mechanical technology, the principles of which were developed in the early nineteenth century, and which has changed little in substance since the 1870s. Media coverage of the factory and its workforce has stressed this industrial heritage and uniqueness. Interestingly, the twisthands -- the skilled operatives who operate the Leavers machines - come from different trades backgrounds: either trained within the Cluny environment, or brought in from outside, where, until relatively recently, they were working in a modern lace-making factory setting. Most also are nearing retirement age, having spent their working lives in the local industry. Yet while the technology and craft remains much as it was one hundred years ago, it lives within an external world that has changed radically. Once the lace they manufactured went to a mass market; now it goes primarily to couture and other specialist outlets. Whilst there is pride and pleasure in the uniqueness of their skill - of being the last twisthands - there is also a nostalgia and regret for a lost time; a certain bemusement at their present predicament where

\footnotetext{
${ }^{22}$ Laurajane Smith and Emma Waterson, 'The envy of the world? Intangible heritage in England', in Laurajane Smith and Natsuko Akagawa (eds), Intangible Heritage (Abingdon, 2009), 289-302.

${ }^{23}$ Vittoria Rosatto, Leavers Lace (Rhode Island, 1948), 12.
} 
the embodied practices of the past and the external world of today collide. This study explores what it means to be a skilled man in this traditional environment, drawing on oral testimony and ethnographic evidence collected over a six-month period within the factory and in the operatives' homes. It does this through the stories they tell about themselves.

\section{Past and Present}

In the years before the First World War, Nottingham truly was the 'City of Lace', famous nationally and internationally, employing some 26,500 men and women in the city and its surrounding area (or about sixty per cent of lace makers in Britain). At its peak, there were roughly 220 firms operating some 2,500 Leavers machines across the county. By the 1940s, however, fewer than 70 firms remained, operating some 860 machines. ${ }^{24}$ Indeed, few industries suffered so sharp a decline during the interwar period, as export markets were lost, manufacture elsewhere expanded (frequently using machines built in Nottingham) and fashions changed. Now there was a 'veritable revulsion from lace', particularly that used in clothing. The 'fancy lace' produced by the Leavers machines was notably demand inelastic across its price range: out of fashion, it did not sell however low the price. Unemployment levels in the industry, despite the protectionist measures introduced in the early 1930s, reached about 25 per cent. Employment in the industry fell to less than half its pre-1914 level and the decline proved to be permanent. ${ }^{25}$ By the 1950 s, census data records that locally only some 4,500 worked in lace manufacture. By the 1970s this had fallen by a further one thousand. A survey in 1959 revealed that only 650 Leavers machines remained, 25 per cent

\footnotetext{
${ }^{24}$ F.A. Wells, 'Manufacturing industry', in K.C. Edwards (ed.), Nottingham and its Region (Nottingham, 1966), 308-9; Board of Trade, Working Party Reports: Lace (London, 1947), 37-9.

${ }^{25}$ F.A. Wells, 'Industrial structure', in Edwards, Nottingham, 406-7; D.E. Varley, A History of the Midland Counties Lace Manufacturers' Association 1915-1958 (Long Eaton, 1959), 132, 142.
} 
of which were idle. ${ }^{26}$ The Leavers section was heavily hit, too, because of the 'increasing use of the inferior but cheaper 'Raschel' lace for edging and other work. ${ }^{27}$ Raschel machines, imported from Germany, were speedier and used semi-skilled labour. By the 1980s, the Leavers industry employed fewer than 200 twisthands, as employers converted to Raschel technology. ${ }^{28}$ Even then UK lace makers could not compete with increasing investment and lower production costs abroad.

It is one of the ironies that Cluny Lace has survived precisely because it sold off its modern Raschel lace-making machinery because of overseas competition, and instead reinvested in second-hand older Leavers technology. The manufacturing processes are very different: Raschel machines knit lace, whereas with Leavers machines the vertical cotton threads are twisted to form the net pattern. Raschel-produced lace is seen by the twisthands as being too perfect, too mechanical, lacking the character - the handmade aspect - of its Leavers counterpart. ${ }^{29}$ The Leavers machine consists of two parts: the portion where the lace is made, and the Jacquard which governs the pattern by moving laterally the many thousands of vertical threads. It does this via paper-thin horizontal perforated strip bars through which the warp threads pass. As these move to left and right, thin circular bobbins, held inside on a carriage, rock to-and-fro in a pendulum-like motion between the warp threads, the bobbin thread twisting around the warp to construct a stable, patterned net. ${ }^{30}$ Currently Cluny has sixteen of these machines, most from the 1900s, some from the 1950s, all made in

\footnotetext{
${ }^{26}$ Shelia Mason, Nottingham Lace 1760s-1950s (Ilkeston, 1994), 110.

${ }^{27}$ East Midlands Economic Planning Council, The East Midlands Study (London, 1966), 38.

${ }^{28}$ David Lowe and Jack Richards, The City of Lace (Nottingham, 1982), 73-4.

${ }^{29}$ Field Notes, 26 March 2013.

${ }^{30}$ For an understanding of the mechanical complexity of the process involved in lace manufacturing, see Twisthands at the Deadstop (a film funded by this project: https://www.youtube.com/watch?v=2mYtIPKmrwo).
} 
Nottinghamshire. Insert Image 1: Levers Machine. In the foreground are hundreds of bobbins in their carriages.

Insert Image 2: Jacquard and droppers, which control the horizontal movement of thin, perforated bars. that control the horizontal movement of the warp threads.

Insert Image 3: Steel droppers, and to the left, the thin, ribbon-like, perforated, steel bars that control the lateral movement of the weft threads.

The Mason family that owns the company are longstanding textile manufacturers. Cluny's employs six twisthands: all white, and all male. ${ }^{31}$ Each twisthand looks after one machine at any one time.

There is a direct sense within the factory of working in the past, not least because it was built in the 1880s. Originally shared with other companies, Cluny is now the sole occupant. One employee recalled: 'I walked through the door... and I thought "We're going back in time here.” I looked round ... I thought, "Bloomin' hell, this looks a bit rough... Crikey, this reminds me of the old days.", ${ }^{32}$ Another noted: 'I've been in a few factories but this is the most antiquated. ${ }^{33}$ There is also an inbuilt sense of decline that taints contemporary understandings. 'When I first started there the factory [Cluny's] was quite full, now it's just sort of dwindled to about twenty [workers]. ${ }^{34}$ Around half the total workforce is nearing or past retirement age. The majority of the operatives started working in the industry in the mid-1960s, and so can remember better times. While the scale of the industry then was a shadow of its former self, at the factory level lace still prospered, and 'whenever fashion

\footnotetext{
${ }^{31}$ Since the fieldwork was completed Cluny have taken on a female twisthand.

${ }^{32}$ Interview 15, 23 August 2013.

33 Interview 16, 7 September 2013; Interview 12, 16 August 2013.

${ }^{34}$ Interview 12, 16 August 2103.
} 
turned towards lace', the production limits of the remaining industry were soon reached, amid a skills shortage. ${ }^{35}$

The Cluny directors are keen to stress that the factory is a business, not a working museum. ${ }^{36}$ For workers, too, it was 'about paying your mortgage at the end of the day. You come here to work to earn your money to live. ${ }^{37}$ Yet the relationship between past and present is not that straightforward. The question hangs: is the factory more a living resemblance of an imagined past, only 'a cottage industry' because of how little 'lace they turn out', made on machines running at a reduced pace because of their fragility, in a working environment and building that belongs to a by-gone age ${ }^{38}$ As one noted, 'I think it's a working museum now... We get lots of visitors anyway. ${ }^{39}$ Another commented: 'What I do is a craft 'cos nobody else does it, and I regard that I work in a museum. These machines are ancient.' ${ }^{40}$ Visits from heritage societies, 'people coming to take photos because it's the last one in the country', similarly bolster this impression. ${ }^{41}$ For Cluny employees, the past/present interface has extra meaning by virtue of their survivor identity. As one twisthand noted: 'we're like dinosaurs, because we're going to be extinct in a minute. There's only 6 of us in the country.' ${ }^{42}$ Did they feel part of the industry's heritage? 'Oh yes. I think we've got to be, because although I wasn't there at the birth I'll certainly be around near the death. So yes,

\footnotetext{
${ }^{35}$ Wells, 'Manufacturing', 309.

${ }^{36}$ Interview 15, 23 August 2013.

${ }^{37}$ Interview 8, 15 May 2013.

${ }^{38}$ Interview 15, 23 August 2013; Interview 14, 23 March 2013.

${ }^{39}$ Interview 14, 23 August 2013.

${ }^{40}$ Interview 15, 23 August 2013.

${ }^{41}$ Interview 14, 23 August 2013.

${ }^{42}$ Interview 4, 18 April 2013.
} 
I've had too many years not to feel that way. ${ }^{43}$ The past meant fuller employment and a significantly more positive industrial landscape: a stable life narrative rooted in work, community and opportunity, rather than the uncertainties of today. It meant greater economic Insert Image 4: Cluny Factory

\section{Insert Image 5: Inside}

freedom and a greater sense of control; an expression of their former independence which no longer existed:

when I first started in the industry, [there were] twelve or fourteen factories within an arm's throw. They [twisthands] used to move around like that, no argument, they just said 'Right, see you' and go to another factory, there were that many. Hundreds. All the lace firms in Long Eaton, you can see all them big factories, they were all full of lace machines. And Nottingham. A vast industry, thousands, don't know where they put it all (laughs). ${ }^{44}$

Asked 'So what is lace to you?', one replied: 'It's been a good living. (laughs) I've never been short of money. We've always had what we wanted, holidays and everything else. ${ }^{45}$

This was a past where if "you were a twisthand you were at the top, top of the money league and all that. That's where your aim was, to be a twisthand. ${ }^{46}$ In the good times, twisthand wages were always high. Prior to the First World War wages averaged around two pounds a week, placing them amongst the highest of manual earners. The industrial historian F.A. Wells described them as 'members of the aristocracy amongst textile workers', heavily

\footnotetext{
${ }^{43}$ Interview 15, 23 August 2013.

${ }^{44}$ Interview 14, 23 August 2013.

${ }^{45}$ Interview 16, 7 September 2013.

${ }^{46}$ Interview 14, 23 August 2013.
} 
unionised in the larger factories. Average piece-rate earnings in the mini-boom of the late thirties stood at around $£ 5.10$ s to $£ 6.10$ s per week, compared to a skilled average of around £4.5.s p.w. In the 1950 s wages in the Leavers section of the trade remained some 10-15 per cent higher than in other branches of the industry, such as plain net or curtain manufacture. Lace wages generally, despite the volatile nature of the industry, continued to expand faster than average weekly wages. ${ }^{47}$ Individual earnings varied according to the skill and quickness of the worker. 'I think in industry in Long Eaton I would imagine we were probably the highest paid people at that time, I'm pretty sure of it. But not now, no we've got left behind. ${ }^{48}$ Lace-maker wages generally in Long Eaton tended to be higher than elsewhere. 'It was all grab, grab, grab in the ' 60 s and ' 70 s and ' $80 \mathrm{~s}$ ', one remembered.

Twisthands, the more they made, the more money they got. You used to get an hourly rate on top for your overtime, but [otherwise] it was all piece work. Get the lace off, get the sets in, get the sets threaded, get the lace off, tie the beams in ... Constantly trying to keep that machine running all day without stopping. ${ }^{49}$

\footnotetext{
${ }^{47}$ F.A Wells, 'The lace industry', in H.A. Silverman (ed.), Studies in Industrial Organisation (London, 1946), 89; Routh, Occupation and Pay, 101; Norman Cuthbert, The Lace Makers' Society: A Study of Trade Unionism in the British Lace Industry, 1760-1960 (Nottingham, 1960), 270. Report on the Census of Production: Lace, 1948, 1958, 1963, 1968 (London); Charles Feinstein, National Income, Expenditure and Output of the United Kingdom 1988-1965 (Cambridge, 1972), T140-1. Pay varied considerably according to the width and speed of the machines, the gauge, the style of work and the kind of yarns used: see Cuthbert, Lace Makers', passim, for a fuller explanation.

${ }^{48}$ Interview 14, 23 August 2013; Interview 15, 23 August 2013.

${ }^{49}$ Interview 14, 23 August 2013.
} 
For those who came late to Cluny from elsewhere it was made clear that their existing piece-rate pay structure was 'well above' what the company could support, and presumably above, too, what Cluny trained twisthands were then being paid. 'But we said we'll just stick it out at Cluny till we retire. ${ }^{50}$ Yet the change from piecework to day rates plus bonuses also impacted on their approach to work. 'There was a lot of stress in those days because you needed to make money, and it's like a disease anyway. Making money was like a disease you're on piece work, you're diseased, it gets to the brain. ${ }^{51}$ One reminisced, 'I think I'm getting to the age now that I like the lace. You have 'two weeks holiday and think "I don't fancy going back to work", but when you get there you're glad you're there making lace again. It's a big part of my life. Everything I own is through the lace trade, nowhere else. ${ }^{52}$ Nonetheless, asked if they thought their current pay reflected the level of skill, the responses were unequivocally negative. 'What, now? No, I don't think it does ... we're probably definitely at the top of our skill factor, we can't go any higher. ${ }^{53}$ Such reconciliation was made harder because the factory itself bolstered this belief. 'Not being big headed. I know how good I am. P... does as well. I would say, myself, I am best twisthand in the world. Charles [the managing director] says that as well. Says we are all the best twisthands in Europe. ${ }^{54}$

For all this apparent 'grab', this is delicate, intense work, and the twisthands take singular pride in the quality of what they produce, in their abilities not to produce flawed work, and in the aesthetic qualities of the product. When the machine is running it requires constant supervision. Broken threads must be tied, empty bobbins replaced, and any

\footnotetext{
${ }^{50}$ Interview 16, 7 September 2013.

${ }^{51}$ Interview 15, 23 August 2013.

${ }^{52}$ Interview 14, 23 August 2013.

${ }^{53}$ Interview 15, 23 August 2013.

${ }^{54}$ Interview 7, 25 April 2013.
} 
imperfection of the pattern must be detected and the appropriate adjustment made. They are also responsible for adjusting the pattern cards on the Jacquard cylinder. This Jacquard harness must be of definite length and tension, and, because variation in temperature affects alignment, frequently careful adjustment is Insert Image 6: Lower part of the machine, showing the warp threads and foot board on which the twisthand stands.

Insert Image 7: Bobbin in its carriage, inserted into its locating comb.

necessary. Twisthands supervise the threading of the machine (putting thousands of warp threads through eyelets and their respective guide-bars) ${ }^{55}$ Certain operations require physical strength, yet other aspects require significant dexterity. 'You've got to be gentle, you've got to be gentle. You've got to have a touch. You've got to have a feel of the yarn as well. ${ }^{56}$ 'It's all in your head, a lot of it, and your hands. You can't take that away from a twisthand. They can spot a mistake a mile off.' 57 'If you want to be a good twisthand, you want to know everything about the machine as well, not just making lace.' 58 'There's that many things that could go wrong it's not really monotonous.' It's 'technically challenging, yes. It's a learning curve. ${ }^{59}$ 'In the old days', one remembered, 'I liked learning.... I've got a thirst for learning, I wanted to improve and I wanted to do things. ${ }^{60}$

When asked whether theirs was a job, an art or a craft (or skill), the consensus was that it was all these things. This craft aspect was fed by the limited scale of the operation and the slower pace of work on old machinery. But the analogies went further than this, linking the Leavers' process to its origins in twisted hand-made bobbin lace: 'that's a craft and I'd like to

\footnotetext{
${ }^{55}$ Wells, 'The lace industry', 87.

${ }^{56}$ Interview 15, 23 August 2013.

${ }^{57}$ Interview 14, 23 August 2013

58 Ibid

${ }^{59}$ Interview 13, 16 August 2013.

${ }^{60}$ Interview 14, 23 August 2013.
} 
think that what I do is a craft.... Leavers, it's so antiquated, it's so crude. We're using the same balancing mechanism that we've used for donkey’s years. ${ }^{, 61}$ The modern Raschel process, by contrast, was seen to be inferior precisely because it produced lace that was too uniform: 'Every breadth is perfect. It's perfect in the fact that it will probably not have as many defects.... It's layered, it hasn't got the 3-D image that this [Leavers] has got.' ${ }^{62}$ Here, the reimagining of past and present brought for some a very personal connection with the product, made possible within the unique manufacturing space that they now occupy: 'Like I've said before, a twisthand is an artist. He's a machine artist', charged with interpreting the patterns and designs into a physical reality. ${ }^{63}$ 'It's an art, I love doing it. ${ }^{64}$ 'I call myself an artist, a lace artist. Because it's a beautiful pattern to make on the machine. It's only me that can do it. Nobody can walk off the street and put that pattern on that machine and make it look beautiful. ${ }^{65}$ Another said:

I like making anything floral... I used to like making bottom bar, beautiful work - fine, wide breadths, beautiful flowing floral patterns, anything like that I like. I don't like making net, just plain net, it's so boring. There's no artistry goes into it. You've got to be an artist to get some of these patterns to work properly, you've got to be an artist. ${ }^{66}$

\footnotetext{
${ }^{61}$ Interview 15, 23 August 2013.

62 Ibid.

${ }^{63}$ Interview 10, 2 July 2013.

${ }^{64}$ Interview 7, 25 April 2013.

${ }^{65}$ Interview 4, 18 April 2013.

${ }^{66}$ Interview 15, 23 August 2013.
} 
'It's beautiful isn't it? ', another remarked. 'I think lace is beautiful' ${ }^{67}$ But the artistry itself was a product of the heuristics underpinned by years of experience and handed-down knowledge, the ability to adjust the movements of the machinery -- juggling around tensions and weightings -- so that it and they can translate the pattern embedded in the jacquard cards to produce the lace.

There existed, also, a strong sense of being in charge: of being 'captain of that machine. You decide how it [the lace] looks. ${ }^{68}$ Such idiosyncrasies would be impossible on modern automated or semi-automated machinery. Being 'in charge' also meant being able to fix any fault or problem: 'because I've been trained to. I've seen all the obstacles all through my working life of what can happen to a machine, and it stays in your head. Knowledge. ${ }^{69}$ In the case of Cluny workers this identity was reinforced by their uniqueness as the last men standing. Asked to define what made a good twisthand, there was a general accord that it was 'Somebody who's definitely got patience.... Once you're out of your training you're more or less on your own, and in those days, like I said before, if you weren't efficient you didn't make money. You certainly had to be patient. ${ }^{, 70}$

Anybody could probably watch a machine and make production, but it's when the machine stops, that's when the twisthand comes to his own. And it's only through many years of experience and looking at the different faults that one can pick up, that you can actually fault find and solve these problems. It takes a long while because there are so many different reasons why one thing can go wrong. ${ }^{71}$

\footnotetext{
${ }^{67}$ Interview 14, 23 August 2013

${ }^{68}$ Interview 15, 23 August 2013.

${ }^{69}$ Interview 10, 2 July 2013.

${ }^{70}$ Interview 15, 23 August 2013.

${ }^{71}$ Interview 11, 2 July 2013.
} 
Yet twisthand lore declares that you 'never ever stop learning. There's no format, there's no one solution that will solve the problem. ${ }^{72}$ Therein lies the skill and the craft, where learned experience, measured in years and the depth of exposure, were deemed central to hierarchical status. Both old and 'young' accepted this as a given. When questioned, one relative 'newcomer' acknowledged that only in the past couple of years had he learnt how to set-up a machine from scratch, completely 'stripping the beams, bobbins and everything out'. 'Ten years in Leavers and you're learning how to set up a machine now...?' 'That's right, yeah. There's still a lot to learn.' Asked about this, 'ten years on the job, he is still learning', one of his senior colleagues replied, 'for a Raschel knitter to come into Leavers, he's done very well. ${ }^{, 73}$

In the world beyond Cluny, technological advances and labour restructuring have changed the relationship between men, machines, and their social understanding of work. Men, it is argued, became more machine minders than had their fathers and grandfathers. To what degree deskilling, coupled with a marked intensification and regulation of work, significantly affected worker status remains contentious. Certainly, the pace of change was uneven across industries, as labour resisted tendencies towards the degradation of work and because work was frequently re-skilled. ${ }^{74}$ Yet older skilled workers particularly were uneasy with less hierarchical forms of flexible working, which undermined their past identities and

\footnotetext{
72 Interview 3, 12 April 2013; Interview 16, 7 September 2013; Interview 13, 16 August 2013.

${ }^{73}$ Interview 5, 25 April 2013; Interview 3, 12 April 2013.

${ }^{74}$ Arthur McIvor, A History of Work (Houndmill, 2001), 43-78; Whitson, 'Craftsmen and skilled, 207-26; Steven Tolliday and Jonathan Zeitlin (eds), The Power to Manage? Employers and Industrial Relations in Comparative Historical Perspective (London, 1991). Charles Moore, 'Reskilling and labour markets in Britain c. 1890-1940: questions and hypotheses', Historical Studies in Industrial Relations, 2 (1996), 93-110.
} 
status. ${ }^{75}$ For those within the Cluny 'bubble', whose immediate working practices had changed but a little, nostalgic reminiscence instead focused on lost status within the community, and their present invisibility in this respect. This past was a world many had only half-known, and whose virtues were likely exaggerated. ${ }^{76}$ The nostalgic, it is argued, 'desires to obliterate history and turn it into a private or collective mythology'. ${ }^{77}$ One younger twisthand supposed: 'It always used to be that the twisthand was a highly respected member of the workforce. They were virtually revered. He made the lace. ${ }^{78}$ An older twisthand remembered:

Over the other side of the canal bridge opposite more or less where the factory was, they were terraced houses and they were all for the workers. The pub on the corner, The Harrington Arms, had a room set aside purely for twisthands. We were quite an elite mob you know. ${ }^{79}$

Manual skill in itself has within it a narrative statement about time, place and status that goes beyond dexterity, knowledge and training. For Cluny workers this is significant, for in this context rare skills are seen as both anachronistic and exceptional: as living heritage. How this plays raises interesting questions about how the past impacts on contemporary

\footnotetext{
${ }^{75}$ Susan Sayce, Peter Ackers and Anne-Marie Greene, 'Work restructuring and changing craft identity: the tale of the disaffected weavers (or what happens when the rug is pulled from under your feet)', Work Employment Society, 21 (2007), 94-95.

${ }^{76}$ David Lowenthal, 'Nostalgia tells it like it wasn't', in Christopher Shaw and Malcolm Chase (eds), The Imagined Past: History and Nostalgia (Manchester, 1989), 29-30.

${ }^{77}$ Svetlanda Boym, The Future of Nostalgia (New York, 2001), xv.

${ }^{78}$ Interview 13, 16 August 2013.

${ }^{79}$ Interview 15, 23 August 2013. See also, Wells, 'The lace industry', 87.
} 
conversations and deeper modes of understanding in the context of identity. The litany of industrial decline was certainly felt sharply. For twisthands the 'biggest change' was lace's 'demise ... happening so quickly.' 'It's very sad, isn't it? It's sad for the industry and it's sad for the country thinking it can do without the lace industry, because it's just proved over the last few years that manufacturing's needed in this country, but it's all gone. ${ }^{80}$ Elsewhere in the factory, the women who repair any flaws in the lace reminisced: 'I'm one of the last lace menders. It scares you to think what's going to happen when I finish ... You sit there sometimes when I'm in that world of my own and think: "Am I the only one that's doing this?" ... I sort of can't believe it. ${ }^{91}$

Yet this very demise has brought with it new identities: where a combination of rare skills, obsolete machinery and an old industrial setting have generated a new interest in who they are and what they do. Unlike the reconstructed open-air industrial museum, the Cluny experience is genuinely 'authentic', even if it speaks to the same types of audience. Most at Cluny welcomed the attention. Increased media publicity has brought an awareness and recognition which they thought previously was sorely lacking, because people thought 'it's all gone' ${ }^{82}$ Asked if 'people had any idea of what was involved in their work', one twisthand replied: 'Thirty years ago they would have done, and twenty years ago they might have done, but now they don't. Even though they've seen it on TV. ${ }^{93}$

Being part of a works performance dovetails neatly with a desire to create a permanent record of what they do before the industry disappears: 'It's good that outside people are taking an interest and it's being documented for the generations to say "Lace? What was that?

\footnotetext{
${ }^{80}$ Interview 15, 23 August 2013; Interview 14, 23 August 2013.

${ }^{81}$ Interview 12, 16 August 2103.

${ }^{82}$ Interview 15, 23 August 2013.

${ }^{83}$ Interview 14, 23 August 2013.
} 
How was that made? Who made that and what were they like?" 84 Suggestions included, for example, encouraging school trips to the factory. Indeed, for some though not all, engagement went further:

I've learned, since all this media coverage. I've gone to these film shows and I've seen some films I've never seen before I must admit, and it's re-educated me. I didn't know half of what I did, what I do now, say twenty years ago, because I was making lace, I didn't need to understand why I made it, I didn't need to understand the history of making lace. But now I've learned a lot about the history of lace and I'm pretty chuffed about that. ${ }^{85}$

Asked whether locals still had a pride in lace manufacture, one replied:

I think they're proud of the heritage it brought, and the factories are still there to show it.... I think the pride shows itself by people bringing it up, especially the heritage societies and that.... I think there should be more of it. ${ }^{86}$

Yet for some, too, there was also a tension between being on display and just wanting to get on with their job: 'Sometimes it does get a bit too much. I come to work here and it's like being in a zoo. Why don't they just go away? We all have a moan about it, I must admit ... I don't want to be on telly. I don't look my best to be on telly, I'm in my scruffs. ${ }^{87}$ Indeed,

\footnotetext{
${ }^{84}$ Interview 13, 16 August 2013.

${ }^{85}$ Interview 15, 23 August 2013.

${ }^{86}$ Interview 14, 23 August 2013.

${ }^{87}$ Interview 12, 16 August 2103.
} 
perhaps not surprisingly, the level of enthusiasm for engagement correlated closely to the established skill hierarchy, so particularly for several of the more outgoing twisthands the explanation of what they did to new external audiences became an extension of this skill and a demonstration of their prowess, whereas for other operatives' work remained essentially just work.

\section{Skill and Divides}

Status and skill run together within Cluny's. The concentration of the trade in a few districts fostered a sense of solidarity and exclusiveness among the twisthand community. This aloofness extended to an initial reluctance to join craft unions, especially in higher paying districts, but trades union membership and recognition expanded during the inter-war years, and significantly so in the $1950 \mathrm{~s}{ }^{88}$ The skill divides also remain heavily gendered, not least because access to skills was strictly gender segregated when most first entered the labour force. ${ }^{89}$ Resistance to female ingression or dilution generally was traditionally strong. ${ }^{90}$ Amongst the twisthands today, opinions were divided about such gender-based divisions: 'It's just like a traditional thing. The men are the twisthands, the females [aren't]. It's keeping tradition alive, if you like.' Yet another thought: 'There's no reason why a woman can't do what I do. I always thought it was physical, but I've observed and proved that it can be done.'91 One of the women workers, however, remembered that at Birkins, she had temporarily operated a Raschel machine. 'They'd never seen a woman on a Raschel warp before ... all the men, kept coming around and looking. .. I got told, we've got a bitch on a

\footnotetext{
${ }^{88}$ Wells, 'The lace industry', 87-8; D.E. Varley, A History of the Midland Counties Lace Manufacturers' Association, 1915-1958, (Long Eaton, 1959), 173.

${ }^{89}$ Board of Trade, Working Party, 40-41.

${ }^{90}$ Wells, 'The lace industry', 87.

${ }^{91}$ Interview 15, 23 August 2013.
} 
warp.' She added, 'I wanted to be a twist hand as well, but they wouldn't let me... I would loved to have run a machine. ${ }^{92}$ 'The men seem to think that they're up there and we're down below', one woman mender remarked of twisthands generally. 'I must admit it does bug me, and they do it because they know it bugs me... I think it probably stems from years and years ago when it first started and the men was it, and it's still sort of there. 93 The women menders hand stitch faults in the lace, where threads have broken or run out. This is skilled but rather tedious work. Several of the twisthands, however, saw things rather differently. 'Some of the menders of yesterday were really, really, skilled people.... But no, the menders we've got now, no. ${ }^{94} \mathrm{He}$ also remembered when, as a charge hand elsewhere, a mender had: started coming down and telling my twisthands ... about their bad work. I had to remonstrate with her. I says, 'Look, you're a mender. If you've got a problem, see the foreman or see me. You don't come down on the shop floor and talk to twisthands about making bad work. That's not your job. That's not within your capacity. ${ }^{95}$

Even within the small works confines of Cluny today, such divides remain very evident. Menders, for example, were told to report faults directly to the twisthand concerned, 'and I know they wasn't happy because I was going to tell them. "You should not come on my footboard. You should not do this" and somebody happened to say, "Well, Charles [the managing director] tells her that she's got to." "Oh, that's all right then." But they didn't like

\footnotetext{
${ }^{92}$ Interview 2, 26 March 2013.

${ }^{93}$ Interview 12, 16 August 2103.

${ }^{94}$ Interview 15, 23 August 2013.

${ }^{95}$ Ibid.
} 
it. ${ }^{96}$ Asked if she thought her job was respected, she replied: 'No. I'm always told that if they didn't leave holes I wouldn't have a job. That's what they tell me. So no, they don't at all.97 She, on the other hand, accepted the gender divide almost unthinkingly: 'it's always been as such. There is no way I could do that [i.e. be a twisthand]. ${ }^{98}$ Another woman employee observed that the best twisthands made it look easy. ${ }^{99}$ Not that the women openly praised them: to their mind the men already had over-inflated egos, so instead they told them they were 'rubbish.' 100 They think of themselves 'as demigods', said one of the women workers. ${ }^{101}$ Another remarked: 'sometimes, the men seem to think that they can't do what we do. Like we thread [insert the thin brass bobbins into steel carriages]. "oh no, we can't do that". Oh, they can do it, but they won't... It's not manly enough. That's a woman's job, not a man's job. ${ }^{102}$ When asked about this gender division, one twisthand replied: 'Well they tend to get the menial jobs, I suppose. Not many men do any threading. I'll do it if you ask me, but I don't particularly like doing it. ${ }^{, 103}$ Another thought, 'I don't want to insult them but for me it's a very mundane job, very repetitive. That's not the sort of job I want to be in. ${ }^{104}$ A woman whose primary responsibility was to wind the thread onto the bobbins, remembered,

\footnotetext{
${ }^{96}$ Interview 12, 16 August 2103.

97 Ibid.

${ }^{98}$ Interview 1, 26 March 2013.

${ }^{99}$ Interview 2, 26 March 2013.

${ }^{100}$ Field Notes, 28 June 2013.

${ }^{101}$ Interview 2, 26 March 2013.

102 Interview 1, 26 March 2013.

${ }^{103}$ Interview 16, 7 September 2013.

${ }^{104}$ Interview 15, 23 August 2013.
} 
'terrible some of them [twisthands] have been in the past... without these ... they can't run the machine, and [yet] they still think they are more important.' ${ }^{105}$

Yet within Cluny's twisthand community there are also significant divisions, built on remembered pasts and reconstructed identities. Its labour force was drawn from two distinct backgrounds. The first were former employees of Birkin. This company had, through the nineteenth and twentieth centuries, been a major employer in the city and its surrounding district. In the post-war period, its Leavers production moved to Long Eaton, and the company began purchasing extra second-hand machinery. It also opened a large new Raschel plant locally in the 1970s, before employment levels fell severely in the 1980s. It ceased production in 2005 .

The ex-Birkins employees joined as apprentices. In the reduced state of the industry, none had close relatives working in Leavers lace. As one recalled:

I'd heard about lace at that particular time because one of the lads from school, he went to work for Byards [local lace manufacturer], ... and he said how good the money was, really good money, and that was it. I wanted to earn as much money as possible at that time. So, we ended up knocking on the door.... Simple as that. ${ }^{106}$

Another remembered: 'It was a good job, well paid. I mean when you leave school, you could find a few jobs to go to, you just picked Leavers. Didn't know what it was at the time. Just walked in this factory. ${ }^{, 107}$ For those companies, like Birkin, which continued to offer formal apprenticeships, the standard period of indenture was six years, only marginally shorter than

\footnotetext{
${ }^{105}$ Interview 2, 26 March 2013.

${ }^{106}$ Interview 15, 23 August 2013.

${ }^{107}$ Interview 14, 23 August 2013
} 
it had been in $1900 .{ }^{108}$ Post-war, this normally included two years of day release at the local technical college. ${ }^{109}$ For ex-Birkin employees, college training - which also included classes in costing, card punching and draughting - 'brought legitimacy to the point of being a twisthand. It made it sound better. You know, you'd been an apprentice, not everybody's been an apprentice, but ... you've got qualifications, the college course and everything. ${ }^{110}$ It taught you things that 'you wouldn't learn at the factory.' ${ }^{111}$ Birkin also had its own on-site training school. Such 'add-ons' raised status. The mantra was: 'we was trained properly.' ${ }^{112}$ It is perhaps odd that formalised learning was so highly valued, when practical learning over theory was generally seen as being central to male-operatives' shop floor self-identity. ${ }^{113}$ If, however, we review this in the overall context of expert knowledge, then its meaning becomes clearer. ${ }^{114}$ Structured training added a layer to their skill set, but also acted as a differentiator. Moreover, 'educated knowledge' was not seen as incompatible with, but rather as an enhancer of, practical skill: it was not theoretical but applied. ${ }^{115}$ It added to personal self-worth: of being valued, that the company placed their training above more immediate production priorities; that they were being taught a wider range of skills that set them ahead of their contemporaries.

\footnotetext{
${ }^{108}$ Mason, Nottingham Lace, 181; More, Skill, 70.

${ }^{109}$ Board of Trade, Working Party, 120-121.

${ }^{110}$ Interview 15, 23 August 2013.

${ }^{111}$ Interview 14, 23 August 2013.

${ }^{112}$ Interview 10, 2 July 2013; Steiger, 'Construction skill', 537.

${ }^{113}$ Paul Willis, "Shop floor culture, masculinity and the wage form", in John Clark, Chas Criticher and Richard Johnson (eds), Working-Class Culture: Studies in History and Theory (London, 1979), 194-5; Collinson,

Managing the Shopfloor, 83-93;

${ }^{114}$ Collins, 'Expert systems’, 329-348.

${ }^{115}$ Mike Savage, Identities and social Change in Britain since 1940: the Politics of Method (Oxford, 2010), 823.
} 
The second group of Cluny employees are essentially home grown. Cluny-based twisthands were always trained on the job. The youngest twisthand, now in his late forties, had previously worked the less-skilled Raschel machinery before Cluny's sold these. He was taught how to operate the Leavers plant by initially shadowing an experienced twisthand for two to three months. 'Everything I've learned has been on the shop floor or from the older guys, or the guys who have been in the trade all their life. I've picked it up that way.' ${ }^{116}$ His mentor had also been trained in this manner:

I spent two months threading, we all had to do that. And then I went on the machine with one of the old twisthands, followed him up and down. And at night, he left $3 / 4$ of an hour early, before we finished. So what he'd do is pull a bunch of threads down and say, put them up. And that's just how you learn. ${ }^{117}$

This is, of course, not to suggest that ex-Birkin employees did not themselves receive on-thejob training. They did. Indeed, Birkin's own training regime had changed by the midseventies, after its school closed because of declining numbers. College attendance for trainees ended in the 1980s, as did formal apprenticeships. Thereafter, Birkin twisthands were trained wholly on the job 'til they were capable for doing it on their own.' ${ }^{118}$ This generally lasted between twelve and eighteen months. It is easy to see, therefore, why the older exBirkin twisthands who worked at Cluny's saw themselves as being part of a properly trained, lost 'golden' age.

\footnotetext{
${ }^{116}$ Interview 13, 16 August 2013.

${ }^{117}$ Interview 9, 28 June 2013.

${ }^{118}$ Interview 6, 25 April 2013.
} 
Yet the past at Birkin was constructed within a broader memory of full employment and prosperity, pride and reminiscence: 'Birkins were always renowned as the best in the world for manufacturing lace. They'd just got the right people and the right machines. Everybody there knew what they were doing, apart from a few. ${ }^{119}$ Even in its declined state, its Leavers operation still employed fifty twisthands, had greater ancillary support, produced a greater variety of products on more complex machines that produced a finer quality of lace. Remembered, too, was the 'camaraderie', of mutual help 'like if you were getting on with a set of carriages, you could guarantee three people would still be running their jobs but they'd come round and they'd help you do it.... Whereas when we went to Cluny, nobody would help you do anything. ${ }^{120}$ And the factory, whilst not new, 'was well kept'. 'You'd got lockers, and everybody had a uniform... whereas when we went to Cluny it was a shock

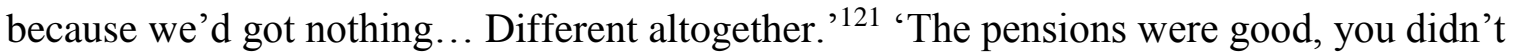
have to pay for your pension. They paid money in every week for a pension for you for life more or less. Whereas compared to Cluny... ${ }^{122}$ 'There were five cleaners there permanently on the floor just sweeping up all the time, keeping the place tidy. Whereas like at Cluny, you know what it's like... everything's falling off the walls. ${ }^{, 23}$ Birkins also offered extra noncash perks, designed to cultivate a workplace 'family culture'. ${ }^{124}$ 'The Christmas do's were phenomenal. You didn't have to pay for a drink, you didn't have to pay for a meal, the firm

\footnotetext{
${ }^{119}$ Interview 16, 7 September 2013.

120 Ibid.

121 Ibid.

122 Interview 14, 23 August 2013.

123 Interview 16, 7 September 2013.

124 Robert Fitzgerald, British Labour Management and Industrial Welfare, 1846-1939 (London, 1988), 94-6; Simon Phillips, "Fellowship in recreation, fellowship in ideals": sport, leisure and culture at Boots Pure Drug Company, Nottingham c.1883-1945', Midland History 29 (2004), 107-123.
} 
did it all.' 125 'They'd got a football team and a cricket team, and a fishing club. In the summer, we had barbecues up at Borrowash, 'cos they’ve got a big field there.' 126

It is noticeable that the two groups do not sit together at breaktimes. ${ }^{127}$ One ex-Birkin employee acknowledged that:

Maybe it's a bit of sour grapes, inasmuch as the Cluny people don't like us because we come over saying 'Oh, when we were at Birkins' ... and people don't like being reminded. 'Oh, when we were at Birkins we did this, we did that' and it's got to be a system that's better than theirs. ${ }^{128}$

Cluny workers, by contrast, thought that the incomers had previously been pampered. 'When you worked here, you did everything yourself, that's pattern change, bar setting, weighting out, whereas the other firms, Birkins, they didn't do anything like that. They all had people to do it for them. Auxiliaries ... That's why if you were trained here, you can work anywhere. ${ }^{129}$ At Birkins, one reminisced, 'I used to be able to say, 'I've got a thread going wrong, can you come down and fix it?' or 'There's a stretch that needs fixing', and the draughtsman would come down and do it for you, but at Cluny Lace you've got to do it yourself'. ${ }^{130}$ Thus, for Cluny operatives, a lack of formalised training was recast as a virtue, where the need to be flexible and a jack of all trades countered Birkin pretensions.

\footnotetext{
${ }^{125}$ Interview 16, 7 September 2013.

126 Ibid.

${ }^{127}$ Field Notes, 16 May 2013.

${ }^{128}$ Interview 15, 23 August 2013.

${ }^{129}$ Interview 9, 28 June 2013.

${ }^{130}$ Interview 15, 23 August 2013.
} 
Internal tensions were thus located around a craft identity based largely not on 'genuine skill', because the skill sets between Birkin and Cluny twisthands are roughly comparable, but instead on how skills and traditions were decoded by individuals and workforce within the factory. ${ }^{131}$ To paraphrase Paul Thompson, this meant 'Playing at being [more] skilled men'. ${ }^{132}$ Yet there was also a prestige derived from having in the past operated the most complicated of the Leavers machinery that made the more dexterous, detailed and delicate patterns. At Birkins, you went from 'top bar, to a single bottom bar, then on to a double bottom bar... They're extremely difficult because you've got two sets of warps and you've got two sets of bars, and you do need a lot of patience to work them. ${ }^{, 133}$ Another remembered: 'You were building your way up. But I was in a bottom bar before I was twenty-five. Double bottom bar, twelve points and all. That's another skill you see. And all machines that was making beautiful lace. And now I am making coarse stuff like this, which I don't mind, it's a job.' 134 'Yet 'not minding', of course, ran counter to an innate sense of a lost past, and a recurrent pride in the skills and prestige upon which it was based.

Notwithstanding, however, the status divides between men and women, or twisthand and twisthand, the greatest divisions remained that between twisthands and everyone else. 'Twisthands', one admitted, 'are a bit snobbish. If you relate twisthands to [Raschel] knitters that's what you get, you get a barrier. I would be insulted to be classed as a knitter.' ${ }^{135}$

\footnotetext{
${ }^{131}$ More, Skill, 16.

${ }^{132}$ Steiger, 'Construction skill', 535-560; Pierre Bourdieu, 'Men and machines', in Karin Knorr-Cetina and Aaron Cicourel (eds), Advances in Social Theory and Methodology: Towards an Integration of Micro-and Macro-Sociologies (London, 1981), 311; Paul Thompson, 'Playing at being skilled men: factory culture and pride in work skills among Coventry car workers', Social History, 13 (1988), 13, 45-49.

${ }^{133}$ Interview 15, 23 August 2013.

${ }^{134}$ Interview 11, 2 July 2013.

${ }^{135}$ Interview 3, 12 April 2013.
} 
Knitters were seen purely as machine minders, not problem solvers. This led, at times, to a lack of respect and a frustration amongst twisthands when working with other, less skilled operatives. ${ }^{136}$ It also found form through a self-belief in their own abilities: 'Well, I like to be perfect in the job I do, and if I did make a mistake I used to worry myself and think 'How have I done that? It's not like me.'137 'We're very proud people [...] a twisthand don't like to be told he's making bad work.... I like [it] to be thought that I'm making a good product and if I'm not, I'd be very disappointed and hurt by it.' ${ }^{138}$

\section{Working with Machines; Working with the Past}

Technical know-how - and the pleasure derived from identifying and interacting with machinery - is still largely conceptualised as something men have and do (and which women largely don't). ${ }^{139}$ Women - at least according to one 1950s survey - are 'not interested in machines as such; they do not try to understand their mechanism and their principle, they do 'not like to play with gadgets as men do'. ${ }^{140}$ But for men, machines can become far more than neutral or inanimate objects. Men seem to develop a greater natural affinity and a greater sense of self-identification with machinery. ${ }^{141}$ Clearly, such fascinations do not extend to all

\footnotetext{
${ }^{136}$ Field Notes 15 May 2103; Interview 3, 12 April 2013.

${ }^{137}$ Interview 14, 23 August 2013.

${ }^{138}$ Interview 15, 23 August 2013.

${ }^{139}$ Line Holth and Ulf Mellström, 'Revisiting engineering, masculinity and technology studies: old structures with new openings', International Journal of Gender, Science and Technology, 3 (2012), 314-329; Ulf Mellström, ‘Technology and masculinity: men and their machines', in Søren Ervø and Thomas Johansson (eds), Among Men: Moulding Masculinities Volume 1 (Aldershot, 2003), 165.

${ }^{140}$ Ferdynand Zweig, Women's Life and Labour, (London, 1952), 90.

${ }^{141}$ Cockburn, Machinery of Dominance, 172-5, 179.
} 
work-based, powered machinery, or to all men. Certain precepts of sense of scale, familiarity, complex interaction, and embodiment apply, precluding machinery such as hand-power tools, or, on a larger scale, industrial hoppers. Yet men are more likely to talk about technology as if it were a toy - something to be enjoyed, discovered and to be engaged with - whereas women see it more as a tool. ${ }^{142}$ Some men talk to their machines, give them feminine names, listen to their rhythms and respond to their quirks; they become emotionally bound to them. ${ }^{143}$ 'You've got to sort of fall in love with the machines you're working with', recalled one engineer. 'You respect 'em.' When machines are abused by careless operators then you feel like 'it's like somebody's ruining your work.' 144

The machines at Cluny offer significant potential for such personification and interaction: big, open, visible, noisy, and with the added historic meaning. It is not difficult to understand why - setting to one side the need to earn a living - embedded craft skills and old machinery co-exist in ways which today are both part industry and part heritage. The factory has some of the largest Leavers machines ever made: $16,000 \mathrm{~kg}$ of cast iron, $15.0 \mathrm{~m}$ long, and 3.0m wide and 4.0m high. Remembering his first encounter with a Leavers machine, many years before, one twisthand recalled thinking:

they were awesome. When I first saw the first lace machine, you looked at it and you saw this banging, clanking monstrosity and there was black lead everywhere and yarn, bits of yarn lying here and there.... So yeah, that seemed a bit intimidating... Crikey, I'm never gonna get this off. ${ }^{145}$

\footnotetext{
${ }^{142}$ Elizabeth Kelan, 'Tools and Toys: Communicating gendered positions towards technology', Information, Communication \& Society, 10 (2007), 357-82.

${ }^{143}$ Mellström, 'Machines and masculine subjectivity', 370-9.

${ }^{144}$ Cited in Cockburn, Machinery of Dominance, 172.

${ }^{145}$ Interview 15, 23 August 2013. Also Interview 14, 23 August 2013.
} 
The sheer volume of noise, one remarked, was initially just overpowering. ${ }^{146}$ It is striking, also, how physically engaged are the twisthands with the machinery as they corrected faults and sorted out other problems. ${ }^{147}$ The mechanics of the machines are just as they had been when they were first built, where age brings its own problems and intimacies.

These machines we run are over a hundred years old...We're working with machines ... that have got a lot of wear on bobbins, carriages, catch bars, com bars, cards, everything wears out very quickly nowadays. It's our job to try and slow that process down. ${ }^{148}$

Consequently, each machine was seen to be different, with its 'own characteristics, its own foibles.' 'Some have cracks, some have had big smashes where they've banged off and been welded together again, so they can get bandages all over them - that's what I call the lumps where they've been welded together.' ${ }^{149}$ It adds to the sense of heritage, and to the sense of specialist expertise. 'Every frame is different, so the more time you're on that one frame, you pick up its little quirks, its little annoyances if you like. ${ }^{150}$ One noted, for example, of the machine on which he was currently working: 'she's very aggressive. I can be as gentle as I like but when I put that button in she's away. She frightens me.' ${ }^{151}$ This individuality meant

\footnotetext{
${ }^{146}$ Interview 16, 7 September 2013.

${ }^{147}$ Field Notes, 26 March 2013.

${ }^{148}$ Interview 15, 23 August 2013.

${ }^{149}$ Interview 14, 23 August 2013.

${ }^{150}$ Interview 13, 16 August 2013.

${ }^{151}$ Interview 15, 23 August 2013.
} 
solutions for one machine might fail on another. ${ }^{152}$ It brings with it its own set of skills. At one level, at least, the machine and twisthand were part of an ongoing conversation: 'I can tell if there's something wrong with the machine by listening to it'; 'You encourage them. 'You will run. Please be co-operative' (laughs).' ${ }^{153}$ For some, this sense of intimacy went further.

All my machines are called Betsy, they're all young ladies. I never swear, I treat them with great respect. I see some twisthands and they make me cringe because, in particular putting a catch bar in, they just let it go and it's such a bang... There's no favouritism, although there are some machines that I prefer to work than others. But when I'm on a machine, I don't tell them that. ${ }^{154}$

Yet even without this romantic sensibility, there existed a clear sense of interactivity between operative and the needs of the machine. This was clearly perceived as being intrinsic to the job, and a central component of the skill. As one twisthand noted: 'we're part of the machine.' It 'can't work without us. There's a connection there. It's not like you just push a button and stand back. ${ }^{155}$ Another added, by way of explanation, that each machine had a 'set routine'. To change this risked 'upsetting' it, and 'once you start upsetting it - you ask lace mechanics - they can be a nightmare.' 156 'I watch you', one of the interviewers said, 'you are like a parent to your machine. You don't wait for it to fall, you kind of catch it

\footnotetext{
${ }^{152}$ Ibid.

${ }^{153}$ Interview 14, 23 August 2013; Interview 13, 16 August 2013.

${ }^{154}$ Interview 15, 23 August 2013.

${ }^{155}$ Field Notes, 6 June 2013.

${ }^{156}$ Interview 15, 23 August 2013.
} 
before it falls.' He replied: 'I am in charge. If anything goes wrong, I've got to be able to fix it. If I can't fix it, then it's something very serious. ${ }^{157}$

Part of the mystique - the overt connection with the past and the old ways - was that this collective knowledge was 'not written down', but instead 'all passed by mouth', from the older guys, some of whom were 'interested in learning you a lot'. ${ }^{158}$ 'Everybody does it different ... everybody's got their own technique and their own way of approaching a problem. ${ }^{159}$ For it to be otherwise - to allow space for a formulaic and not a bespoke response - would devalue the craft of the operative. Indeed, the technical challenges were listed as being a key part of the interest in the job: 'there's always something new. You might think it's the same but it's not, there's always something else. It does keep you interested.'160 The more technically demanding, the greater the pleasure: 'I like the challenge. I mean sometimes you think to yourself, "I'm getting mad, I'm getting really frustrated" and I'm thinking, "I'll get it, I'll crack it." It might take me a day, two days, but you persevere through all the rituals that a normal twisthand would go through, all the basics. ${ }^{161}$ Being able to fix any problem, deriving workplace satisfaction from problem-solving capacity, and mastering the minutiae of the craft built on the core declaimer that 'twisthands can do everything. ${ }^{, 162}$ Insert Image 8: Lace still on the machine Insert Image 9: Leavers Lace_2

\footnotetext{
${ }^{157}$ Interview 11, 2 July 2013.

${ }^{158}$ Interview 3, 12 April 2013; Interview 10, 2 July 2013; Interview 14, 23 August 2013.

${ }^{159}$ Interview 3, 12 April 2013.

${ }^{160}$ Interview 13, 16 August 2013.

${ }^{161}$ Interview 15, 23 August 2013.

${ }^{162}$ Interview 9, 28 June 2013; Interview 13, 16 August 2013.
} 


\section{Lost Worlds}

It would be easy to forget that the company's main objective is to make profits and its operatives wages to live by. Yet this project was funded, primarily, because of its industrial heritage context; to provide a record of the last factory in the country to make Leavers lace, which employs the few remaining twisthands who can understand the process and operate the machinery. The past is embedded in the machinery, the fabric of the building, and in its operating practices. Visitors come to the factory because of a fascination with the mechanics of the process and the visual impressiveness of the machines, but they also view these through a local and national context of loss. Cluny Lace offers a glimpse of bygone manufacturing, and a measure of post-industrial change. It taps into the remembered (or imagined) stable life narratives of yesterday, which were rooted in the world of work. Visitors, according to one worker, expected some form of Victorian montage when they arrived: 'They think you're sort of sitting there... I mean, we get a lot of visitors and I think they think that's what they're gonna find., 163

Ex-Birkin workers particularly remember the past differently: a world not just of higher wages, but of better working conditions and greater status (even though the industry was already in decline). 'They were the [biggest and] best lace firm in Europe, by far.' 164 'We was trained properly.' ${ }^{165}$ 'We used to hire trains and go to Portsmouth or the seaside, it was a proper good social club.' ${ }^{166}$ For these workers, Cluny's is anachronistic, yet interestingly, and perhaps consequently, it is these operatives that show the greater interest in publicly displaying their craft. 'I think there should be more of it. They should give people more

\footnotetext{
${ }^{163}$ Interview 2, 26 March 2013.

${ }^{164}$ Interview 4, 18 April 2013.

165 Interview 10, 2 July 2013.

166 Interview 14, 23 August 2013.
} 
chance to see ... what the lace trade is. ${ }^{167}$ Setting aside divisions over who'd received the best training, or who'd been pampered or not, amongst all twisthands there is an acute understanding of the uniqueness of their skills, in which they take a significant and understandable pride. The machinery and processes are mechanically complex, made more so by the age of the equipment. 'They're all a challenge and it keeps everything fresh', remarked one when asked if had a favourite machine. ${ }^{168}$ None of the twisthands see themselves as being machine minders. They are very much men in charge, managing huge pieces of machinery, solving problems and optimising machine performance according to unwritten rules. And, too, of being 'part of the machine' - offering an interconnectivity between twisthand and $16,000 \mathrm{~kg}$ of animated cast iron. As one noted, 'it's a question of feeling between the machines. How I feel and how the machine works. Its knowing all the little foibles they have.' 169 'It's not something you pick up in five minutes', remarked another. It is 'a skill. There's an art to everything and it is a skilled trade, a craft. ${ }^{, 170}$

This interaction of men and machinery makes Cluny's a place where past and the present come together, as both a physical space of heritage and of contemporary memory. Yet while it functions as an example of living history, it sells its product directly to the trade, and not to the visitors. It is also a conflictual site where the past and the present have an uneasy relationship. Within, there is a nostalgia for an industry near extinct, but also a frustration for the foreseeable loss of work-based skill that only just survives. What had the lace industry meant to these men? Financial stability, community status, a place in the world, but also they made the lace that made Nottingham famous. 'I'm one of the last few twisthands left, we're

\footnotetext{
${ }^{167}$ Ibid.

${ }^{168}$ Interview 13, 16 August 2013.

${ }^{169}$ Interview 3, 12 April 2013.

${ }^{170}$ Interview 13, 16 August 2013.
} 
leaving a legacy behind and I'm proud about that', one remarked. ${ }^{171}$ Nottingham lace largely now lives as a memory; not as a thing of contemporary substance. In this, of course, it is not unique, having something in common, for example, with the immediate surrounding pit villages where coal is also a memory. We started by asking the question: what it means to be a skilled man working in such an environment? 'It doesn't change the way I work at all. I still work as though I'm working for Birkins. I think when you've worked as long as we have, it's habit, you can't get out the habit.' Yet he added, 'Since all this media coverage has come out it's made my job feel more worthwhile. I've got on with management better. I've gone to film shows with them, I've gone to talks with them, and I talk to them as part of it., 172

\footnotetext{
${ }^{171}$ Interview 15, 23 August 2013.

${ }^{172}$ Ibid.
} 